\title{
Asupan energi dan protein pasien tidak berbeda menurut tingkat kepercayaan diri dan kinerja ahli gizi dalam menerapkan proses asuhan gizi terstandar
}

\author{
Patients energy and protein intake were not different based on dietitians self-confidence and \\ performance in implementiation of standardized nutrition care process
}

Merryna Nia Silvia', Martalena BR Purba², Endy Parjanto ${ }^{3}$

\begin{abstract}
Background: The incidence of hospital malnutrition is still high. Prevalence of malnutrition was 56.9\% at three hospital in Indonesia, such as Dr. Sardjito Hospital Yogyakarta, Jamil Hospital Padang, and Sanglah Hospital Bali. Diet therapy might improve nutritional intake. Standardized nutrition care process (SNCP) helps dietitian to make a decision with critical thinking to improve the quality of nutritional care, i.e. safe and effective. Dietitians need self-confidence in applying their knowledge to accomplish their works. Several studies showed that higher self-confidence correlated with higher performance. That would have positive impact on patients outcomes.

Objectives: To find out the differences in patient energy and protein intake based on dietitians selfconfidence in implementing SNCP.

Methods: An observational study was used in this study with cross sectional design involving dietitians and hospitalized patients in Dr. Sardjito Hospital Yogyakarta. Data were analyzed using independence $t$ test, chi-square, and Anova.

Results: There was no significant difference in percentage average of patients energy intake of high self confidence compared to low self confidence (lower $6.3 \%, p=0.13$ ), as well as in protein intake (higher $1.8 \%, p=0.73)$. The percentage average of energy in nutritional intake, which energy intake was $3.0 \%$ $(p=0.49)$ lower in good performance and protein intake was $7.1 \%(p=0.20)$ higher in good performance, had no statistical difference with dietitians performance. There was also no statistical difference between dietitians performance and dietitians self-confidence $(p=0.23)$.

Conclusions: There were no differences between average percentage of energy and protein intake with dietitians self-confidence and dietitians performance. There was also no difference between dietitians performance and their self-confidence.
\end{abstract}

KEYWORDS: self-confidence, dietitians performance, energy and protein intake

\begin{abstract}
ABSTRAK
Latar belakang: Kejadian hospital malnutrition masih tinggi. Prevalensi malnutrisi di tiga rumah sakit di Indonesia, yaitu RSUP Dr. Sardjito Yogyakarta, RSUP Jamil Padang, dan RSUD Sanglah Bali sebesar 56,9\%. Terapi diet dapat meningkatkan asupan gizi proses asuhan gizi terstandar (PAGT) membantu ahli gizi membuat keputusan dengan berpikir kritis dalam upaya meningkatkan kualitas asuhan gizi yang aman dan efektif. Ahli gizi memerlukan kepercayaan diri dalam melaksanakan tugasnya. Beberapa penelitian medis menunjukkan bahwa kepercayaan diri yang tinggi berhubungan dengan kinerja yang lebih baik. $\mathrm{Hal}$ tersebut dapat berdampak positif terhadap outcome pasien.

Tujuan: Untuk mengetahui perbedaan asupan energi dan protein pasien menurut tingkat kepercayaan diri dan kinerja ahli gizi dalam menerapkan PAGT.
\end{abstract}

\footnotetext{
1 Pasca Sarjana IImu Kesehatan Masyarakat Minat Utama Gizi dan Kesehatan Fakultas Kedokteran Universitas Gadjah Mada, Jl. Farmako Sekip Utara Yogyakarta 55281, e-mail:mer_nia@yahoo.com

2 Bagian Instalasi Gizi RSUP Dr. Sarjito, Jl. Kesehatan Yogyakarta, e-mail: martalena_purba@yahoo.com

${ }^{3}$ Bagian Anak RSUP Dr. Sardjito, Jl. Kesehatan Yogyakarta
} 


\begin{abstract}
Metode: Jenis penelitian ini adalah observasional dengan rancangan cross sectional. Subjek penelitian adalah ahli gizi dan pasien rawat inap RSUP Dr. Sardjito Yogyakarta, dengan masing-masing berjumlah 12 subjek dan 90 subjek, menggunakan teknik convenience sampling dan quota sampling. Penelitian dilaksanakan pada bulan Desember 2013 sampai Maret 2014. Analisis data secara bivariat dilakukan dengan uji t, chi-square, dan anova.

Hasil: Asupan energi pasien pada kepercayaan diri ahli gizi baik tidak berbeda dengan kepercayaan diri ahli gizi yang tidak baik (lebih rendah 6,3\%, $p=0,13$ ), demikian juga dengan asupan protein (lebih tinggi $1,8 \%, p=0,73)$. Tidak ada perbedaan rerata persentase asupan energi, yaitu selisih $3,0 \%(p=0,49)$ lebih rendah pada kinerja baik dan protein $7,1 \%(p=0,20)$ lebih tinggi pada kinerja baik. Tidak ada perbedaan kinerja ahli gizi menurut tingkat kepercayaan dirinya $(p=0,23)$.

Kesimpulan: Tidak ada perbedaan asupan energi dan protein menurut tingkat kepercayaan diri dan kinerja ahli gizi, serta kinerja menurut tingkat kepercayaan diri ahli gizi.
\end{abstract}

KATA KUNCl: kepercayaan diri, kinerja ahli gizi, asupan energi dan protein

\section{PENDAHULUAN}

Kejadian hospital malnutrition di luar negeri maupun dalam negeri masih tinggi. Studi epidemiologis di Amerika Latin melaporkan bahwa $50,2 \%$ pasien rawat inap menderita malnutrisi (1), sedangkan dari 25 rumah sakit di Brazil terdapat $27 \%$ pasien malnutrisi mengalami komplikasi (2). Sebuah penelitian menunjukkan bahwa terdapat $52 \%$ prevalensi malnutrisi pada pasien bedah (3). Penelitian lain juga menunjukkan sebanyak $40 \%$ pasien intensive care unit (ICU) mengalami malnutrisi (4).

Prevalensi malnutrisi pada tiga rumah sakit di Indonesia, yaitu RSUP Dr. Sardjito Yogyakarta, RSUP Jamil Padang, dan RSUD Sanglah Bali sebesar 56,9\% (5). Prevalensi malnutrisi pada anak balita di RSUP Sanglah Bali sebesar 30,1\%, sedangkan pada anak usia 0-18 tahun di RS Dr. Wahidin Sudirohusodo Makassar sebesar 8,9\% $(6,7)$. Malnutrisi terjadi pada $40-60 \%$ pasien rawat inap dengan penyakit akut dan pasien yang saat awal masuk tanpa masalah gizi sering menunjukkan penurunan status gizi dalam kurun waktu tiga minggu (8). Tingginya prevalensi malnutrisi yang terjadi di rumah sakit dihubungkan dengan ketidakmampuan dan kurangnya kesadaran tenaga kesehatan di rumah sakit dalam mengidentifikasi dan mengatasi masalah malnutrisi (9), dan karena pelayanan gizi yang tidak tepat akibat aktivitas klinis yang tidak sesuai dengan standar (10). Terdapat sebanyak $40 \%$ pasien tidak dikenali status gizinya karena tidak diskrining saat masuk rumah sakit, sehingga pasien tidak memperoleh asuhan gizi sesuai kebutuhannya (10). Penurunan status gizi selama di rumah sakit meningkatkan risiko komplikasi penyakit 2,7 kali, memperpanjang lama rawat 6,3 sampai 11,9 kali dan peningkatan biaya perawatan 1,8 kali $(5,11)$.

Terapi diet berkualitas yang dilakukan oleh ahli gizi rumah sakit dapat meningkatkan asupan gizi, status gizi, dan memperpendek lama rawat pasien di rumah sakit $(12,13)$. Proses asuhan gizi terstandar (PAGT) merupakan suatu model baru dari asuhan gizi yang terdiri dari 4 langkah yang berurutan dan saling berkaitan, yaitu pengkajian gizi, diagnosis gizi, intervensi gizi, serta monitoring dan evaluasi gizi, yang membantu ahli gizi untuk membuat keputusan dengan berpikir kritis dalam upaya meningkatkan kualitas pemberian asuhan gizi yang aman dan efektif dalam menangani masalah gizi sehingga masalah gizi pasien dapat diatasi (13-15).

Ahli gizi merupakan seseorang yang memiliki kemampuan berfikir secara kritis untuk mendiagnosis masalah gizi serta merekomendasikan perawatan gizi untuk mengatasi masalah gizi pasien (16). Selain itu, ahli gizi memerlukan kepercayaan diri dalam menerapkan pengetahuannya, sehingga dapat memberikan kekuatan dan kemampuan untuk menggunakan bakatnya. Dukungan yang diberikan ahli gizi terhadap tenaga medis yang lain juga dapat meningkatkan kepercayaan diri membuat diagnosis yang tepat sesuai kondisi pasien (17). Beberapa penelitian medis menunjukkan bahwa kepercayaan diri yang tinggi berhubungan dengan kinerja yang 
lebih baik $(18,19)$. Kualitas pelayanan ahli gizi dapat dinilai melalui kinerja yang dicapai dan ketaatan dalam melakukan proses terstandar, yaitu PAGT (13). Hal tersebut dapat ditetapkan kepada ahli gizi dalam melakukan PAGT sehingga ahli gizi merasa mampu dan percaya diri mengatasi masalah gizi yang berdampak positif terhadap outcome pasien. Berdasarkan uraian di atas, penelitian ini bertujuan untuk mengevaluasi perbedaan asupan gizi pasien menurut tingkat kepercayaan diri ahli gizi dalam menerapkan PAGT.

\section{BAHAN DAN METODE}

Penelitian ini merupakan penelitian observasional dengan rancangan cross sectional. Penelitian dilaksanakan di ruang rawat inap instalasi rawat inap I (IRNA I), yaitu Anggrek 1-2, Bugenvil 1-2, Cendana 1-5, dan Dahlia 1-4, instalasi maternal perinatal (IMP), instalasi rawat intensif anak (IRIA) - luka bakar, instalasi kesehatan anak (INSKA), intermediate care (IMC), dan unit stroke di RSUP Dr. Sardjito Yogyakarta. Pemilihan lokasi penelitian pada rumah sakit yang telah melaksanakan PAGT. Penelitian ini dilaksanakan pada bulan Desember 2013 sampai dengan Maret 2014.

Populasi dalam penelitian ini adalah ahli gizi dan pasien rawat inap. Subjek penelitian ini ialah ahli gizi yang bekerja di ruang rawat inap RSUP Dr. Sardjito yang memenuhi kriteria inklusi, yaitu telah menjalankan pendidikan minimal D3 gizi, menerapkan PAGT dalam menangani pasien di ruang rawat inap minimal 6 bulan, dan bersedia menjadi subjek penelitian dengan menandatangani formulir kesediaan menjadi responden. Pasien rawat inap diikutsertakan ke dalam penelitian bila telah ditangani ahli gizi dengan PAGT, mendapatkan makanan dari rumah sakit selama 3 hari, tidak menerima pemberian makanan melalui enteral feeding dan total parenteral nutrition (TPN), serta bersedia menjadi subjek penelitian dengan menandatangani formulir kesediaan menjadi responden. Kriteria drop out pasien, yaitu dalam tiga hari mendapatkan enteral feeding atau TPN.

Besar sampel ahli gizi diambil secara convenience sampling, yaitu 12 subjek. Besar sampel pasien rawat inap adalah 90 subjek didasarkan atas perhitungan rumus pendugaan proporsi populasi (20) dengan presisi (d) 10\%, tingkat kemaknaan $\left(Z_{1-\propto / 2}\right) 0,05$, dan proporsi $(p)$ 0,325 . Setelah dilakukan uji normalitas, terdapat 8 outlier yang dihapus, sehingga terdapat 82 subjek yang dianalisis.

Kuesioner tingkat kepercayaan diri ahli gizi dimodifikasi dari kuesioner kepercayaan diri Peter Lauster (21). Kuesioner tingkat kepercayaan diri telah melalui uji validitas dan reliabilitas sebelum digunakan dengan menggunakan Pearson product moment, sedangkan uji reliabilitas menggunakan cronbach alpha. Uji coba dilakukan kepada 10 orang ahli gizi yang berasal dari RSUP Dr. Sardjito Yogyakarta dan RS Panti Rapih Yogyakarta. Hasil uji validitas diperoleh nilai $r$ tabel $(n=10)$ adalah 0,6315 $(\alpha=5 \%)$ dan menunjukkan nilai $r$ hitung >nilai $r$ tabel. Hasil uji reliabilitas menunjukkan nilai alpha 0,9484, sehingga pertanyaan pada kuesioner dinyatakan reliabel. Setelah diuji, terdapat 17 pertanyaan yang valid dan reliabel dengan skala jawaban 1-4 (tidak pernah, jarang, sering, dan sangat sering). Kinerja ahli gizi yaitu keluaran kerja ternilai seorang ahli gizi yang ada hubungannya dengan PAGT. Cara mendapatkan data kinerja dengan menggunakan kuesioner yang terdiri dari 12 pertanyaan dengan skala jawaban ya dan tidak, yang diukur sesuai dengan jumlah kasus yang ditangani oleh ahli gizi. Cut off ditentukan berdasarkan nilai rerata. Kinerja ahli gizi diklasifikasikan menjadi baik jika nilai $\geq 7$ dan kurang jika nilai $<7$ dengan skala ordinal.

Ahli gizi diwawancara dan memilih salah satu jawaban pada masing-masing pertanyaan. Kinerja dan tingkat kepercayaan diri ahli gizi diukur oleh peneliti pada setiap saat ahli gizi mendapatkan pasien. Asupan makan dan cita rasa makanan pasien diamati selama 3 hari. Jumlah makanan dan minuman dari dalam dan luar RS yang dikonsumsi pasien dikumpulkan dengan metode recall dan penimbangan makanan sisa (makanan yang disajikan atau sisanya). Asupan gizi pasien dari dalam rumah sakit diperoleh dari jumlah nilai asupan gizi hasil konversi standar makanan rumah sakit, sedangkan asupan pasien di luar rumah sakit dianalisis menggunakan program Nutrisurvey. 
Perbedaan asupan gizi pasien menurut tingkat kepercayaan diri dan kinerja ahli gizi dianalisis dengan uji t independen, perbedaan kinerja ahli gizi menerapkan PAGT menurut tingkat kepercayaan diri ahli gizi diuji dengan uji chi-square, perbedaan asupan energi dan protein pasien menurut anoreksia, gangguan gastrointestinal, terapi obat, cita rasa makanan, dan pendidikan pasien diuji dengan uji $t$ independen, perbedaan asupan energi dan protein pasien menurut penyakit menggunakan uji Anova. Penelitian ini telah disetujui berdasarkan ethical clearance dari Komisi Etik Penelitian Kedokteran dan Kesehatan Fakultas Kedokteran Universitas Gadjah Mada dengan nomor Ref: KE/FK/110/EC.

\section{HASIL}

Karakteristik ahli gizi pada penelitian ini menunjukkan bahwa sebagian besar $(67 \%)$ ahli gizi berumur $>35$ tahun, perempuan $(67 \%)$, latar belakang pendidikan DIV $(50 \%)$, dengan masa kerja $>7$ tahun $(83 \%)$. Sebagian besar pasien adalah perempuan $(56 \%)$, dewasa $(70 \%)$, tingkat pendidikan rendah $(63 \%)$, menggunakan kelas III (49\%), tidak bekerja atau pensiunan $(46 \%)$. Jenis diet yang diberikan pada pasien subjek penelitian yaitu tinggi energi tinggi protein (TETP) $(23 \%)$, DM (15\%), diet jantung (DJ) $(7 \%)$, rendah protein rendah garam rendah kalium (RPRGRK) $(6 \%)$, ibu menyusui (9\%), dan lain-lain (40\%) (Tabel 1 dan Tabel 2) .

Tabel 1. Karakteristik ahli gizi

\begin{tabular}{lcc}
\hline Karakteristik & $\mathbf{N}$ & \% \\
\hline Umur & & \\
$\quad \leq 35$ tahun & 4 & 33 \\
$\quad>35$ tahun & 8 & 67 \\
Jenis kelamin & & \\
$\quad$ Laki-laki & & 33 \\
$\quad$ Perempuan & 4 & 67 \\
Pendidikan & 8 & \\
$\quad$ DIII & & 25 \\
DIV & 3 & 50 \\
S1 & 6 & 25 \\
Masa kerja & 3 & \\
$\quad \leq 7$ tahun & & 17 \\
$>7$ tahun & 2 & 83 \\
\hline
\end{tabular}

Tabel 2. Karakteristik pasien

\begin{tabular}{|c|c|c|}
\hline Karakteristik & $\mathbf{n}$ & $\%$ \\
\hline \multicolumn{3}{|l|}{ Jenis kelamin } \\
\hline Laki-laki & 36 & 44 \\
\hline Perempuan & 46 & 56 \\
\hline \multicolumn{3}{|l|}{ Umur } \\
\hline$\leq 19$ tahun & 10 & 12 \\
\hline 20-59 tahun & 57 & 70 \\
\hline$\geq 60$ tahun & 15 & 18 \\
\hline \multicolumn{3}{|l|}{ Tingkat pendidikan } \\
\hline Rendah & 52 & 63 \\
\hline Tinggi & 30 & 37 \\
\hline \multicolumn{3}{|l|}{ Kelas perawatan } \\
\hline I & 5 & 6 \\
\hline II & 37 & 45 \\
\hline III & 40 & 49 \\
\hline \multicolumn{3}{|l|}{ Pekerjaan } \\
\hline Tidak bekerja & 38 & 46 \\
\hline PNS/TNI/POLRI & 2 & 3 \\
\hline Wiraswata & 11 & 13 \\
\hline Karyawan swasta & 5 & 6 \\
\hline Petani/buruh & 17 & 21 \\
\hline Lain-lain & 9 & 11 \\
\hline \multicolumn{3}{|l|}{ Jenis diet } \\
\hline Makanan biasa & 30 & 37 \\
\hline Tinggi energi tinggi protein (TETP) & 19 & 23 \\
\hline Diabetes mellitus (DM) & 12 & 15 \\
\hline $\begin{array}{l}\text { DM rendah protein rendah garam rendah } \\
\text { kalium (DM RPRGRK) }\end{array}$ & 1 & 1 \\
\hline Diet jantung (DJ) & 6 & 7 \\
\hline Diet hati $(\mathrm{DH})$ & 1 & 1 \\
\hline Rendah kolesterol (R. Chol) & 1 & 1 \\
\hline $\begin{array}{l}\text { Rendah protein rendah garam rendah } \\
\text { kalium (RPRGRK) }\end{array}$ & 5 & 6 \\
\hline Ibu menyusui & 7 & 9 \\
\hline
\end{tabular}

Rerata asupan energi pasien anak adalah 2.060 kkal (1.577,5 kkal atau $77 \%$ dari rumah sakit), sedangkan rerata asupan protein adalah $68,4 \mathrm{~g}(53,2 \mathrm{~g}$ atau $78 \%$ dari rumah sakit). Rerata asupan energi dan protein pasien dewasa adalah masing-masing 1.699,1 kkal (1.495,3 kkal atau $88 \%$ dari rumah sakit) dan 60,6 $\mathrm{g}(55,7 \mathrm{~g}$ atau $92 \%$ dari rumah sakit). Jumlah pasien yang ditangani ahli gizi dengan tingkat kepercayaan diri yang baik berjumlah 51 orang, sedangkan oleh ahli gizi kinerja yang baik berjumlah 57 orang.

Hasil penelitian menunjukkan tidak ada perbedaan rerata persentase asupan energi dan protein menurut tingkat kepercayaan diri dan kinerja ahli gizi (Tabel 3). 
Tabel 3. Rerata persentase asupan energi dan protein pasien menurut tingkat kepercayaan diri dan kinerja ahli gizi

\begin{tabular}{|c|c|c|c|c|}
\hline Variabel & $\begin{array}{c}\text { Persentase asupan energi } \\
\text { pasien (mean } \pm S D)\end{array}$ & $\mathbf{p}$ & 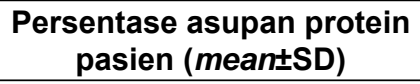 & $\mathbf{p}$ \\
\hline \multicolumn{5}{|c|}{ Tingkat kepercayaan diri ahli gizi } \\
\hline Baik & $84,5 \pm 19,4$ & 0,13 & $95,3 \pm 24,2$ & 0,73 \\
\hline Kurang & $90,8 \pm 15,4$ & & $93,5 \pm 21,7$ & \\
\hline \multicolumn{5}{|l|}{ Kinerja ahli gizi, } \\
\hline Baik & $86,0 \pm 17,8$ & 0,49 & $96,8 \pm 24,8$ & 0,20 \\
\hline Kurang & $89,0 \pm 18,9$ & & $89,7 \pm 18,4$ & \\
\hline
\end{tabular}

Hasil penelitian menunjukkan bahwa tidak terdapat perbedaan kinerja ahli gizi menurut tingkat kepercayaan diri (Tabel 4).

Tabel 4. Perbedaan kinerja ahli gizi menurut tingkat kepercayaan diri

\begin{tabular}{|c|c|c|c|c|c|c|}
\hline \multirow{3}{*}{$\begin{array}{l}\text { Tingkat } \\
\text { kepercayaan } \\
\text { diri ahli gizi }\end{array}$} & \multicolumn{4}{|c|}{ Kinerja ahli gizi } & \multirow{3}{*}{$x^{2}$} & \multirow{3}{*}{$\mathbf{p}$} \\
\hline & \multicolumn{2}{|c|}{ Baik } & \multicolumn{2}{|c|}{ Kurang } & & \\
\hline & $\mathrm{n}$ & $\%$ & $\mathrm{n}$ & $\%$ & & \\
\hline Baik & 33 & 65 & 18 & 35 & 1,4705 & 0,23 \\
\hline Kurang & 24 & 77 & 7 & 23 & & \\
\hline
\end{tabular}

Rerata persentase asupan energi dan protein lebih rendah secara bermakna pada pasien yang mengalami anoreksia dan gangguan gastrointestinal, sedangkan penyakit, terapi obat, cita rasa makanan, dan pendidikan pasien tidak menunjukkan adanya perbedaan asupan gizi (Tabel 5).

\section{BAHASAN}

\section{Asupan gizi pasien menurut tingkat kepercayaan diri ahli gizi}

Penelitian ini menunjukkan tidak ada perbedaan rerata persentase asupan energi maupun protein pasien berdasarkan tingkat kepercayaan diri ahli gizi. Hal ini mungkin disebabkan adanya faktor lain yang mempengaruhi di luar variabel, misalnya peran seorang petugas kesehatan mencakup pada kompetensi atau keahlian yang dimiliki dan dukungan dari petugas medis yang lain, peran tenaga medis lain ketika menangani kasus pasien, peran ahli gizi atau tenaga medis lainnya (kesehatan) secara tunggal, tidak dapat membantu penyembuhan pasien secara maksimal. RSUP Dr. Sardjito menyediakan lembar konsultasi antartenaga medis yang dapat ditujukan ke bagian tertentu sesuai dengan permasalahan pasien, salah satunya misalnya ke petugas gizi untuk menangani masalah kebutuhan gizinya.

Sebuah penelitian menunjukkan bahwa ahli gizi yang aktif berkoordinasi dengan tenaga medis lainnya, mulai dari tahapan perencanaan, intervensi, sampai monitoring dan evaluasi diet pasien, mendapatkan hasil asupan gizi pasien yang lebih besar dibandingkan dengan ahli gizi yang tidak aktif. Koordinasi antartenaga medis sangatlah dibutuhkan supaya masalah pasien dapat dipecahkan bersama $(12,13)$. Beberapa penelitian menemukan bahwa kurangnya pelatihan dan kepedulian tenaga medis akan mengakibatkan kurang optimalnya pelayanan gizi terhadap pasien rawat inap (22). Penelitian terhadap dokter dan perawat di rumah sakit di Skandinavia menunjukkan perbedaan antara sikap dengan penerapan gizi, terutama skrining dan monitoring terhadap pasien. Penerapan tersebut hanya dilakukan oleh sebagian kecil responden, meskipun terdapat $90 \%$ responden yang setuju untuk mengusahakan dan memfokuskan penerapan gizi pada pasien. Hal ini menunjukkan bahwa penerapan gizi yang baik masih agak sulit untuk dilakukan. Namun demikian, penelitian beberapa tahun terakhir di Eropa menunjukkan peningkatan perawatan gizi yang dilakukan. Untuk itu dibutuhkan perjuangan agar asupan gizi pasien sesuai dengan kebutuhan dan mencegah penyakit yang berkaitan dengan kejadian malnutrisi (23).

Sebuah penelitian menunjukkan bahwa semakin banyak pengalaman dan penggunaan kemampuan dalam konseling gizi, seorang ahli gizi akan merasa semakin percaya diri. Pengalaman yang banyak dapat juga dikaitkan dengan masa kerja. Ahli gizi yang masa kerjanya lebih dari 7 tahun memiliki kinerja yang lebih 
Tabel 5. Rerata persentase asupan energi dan protein pasien menurut kondisi anoreksia, gangguan gastrointestinal, penyakit, terapi obat, cita rasa, dan pendidikan pasien

\begin{tabular}{|c|c|c|c|c|}
\hline Variabel & $\begin{array}{l}\text { Persentase asupan } \\
\text { energy (mean } \pm S D)\end{array}$ & $\mathbf{p}$ & $\begin{array}{c}\text { Persentase asupan } \\
\text { protein }\end{array}$ & $\mathbf{p}$ \\
\hline \multicolumn{5}{|l|}{ Anoreksia } \\
\hline Ya & $72,1 \pm 20,5$ & 0,0003 & $77,7 \pm 21,9$ & 0,001 \\
\hline Tidak & $90,2 \pm 15,9$ & & $98,4 \pm 21,9$ & \\
\hline \multicolumn{5}{|c|}{ Gangguan gastrointestinal $^{\$}$} \\
\hline $\mathrm{Ya}$ & $71,5 \pm 18,9$ & $<0,001$ & $81,0 \pm 24,5$ & 0,001 \\
\hline Tidak & $92,2 \pm 14,6$ & & $99,3 \pm 20,9$ & \\
\hline \multicolumn{5}{|l|}{ Penyakit $^{*}$} \\
\hline i & $89,2 \pm 16,7$ & 0,08 & $92,6 \pm 19,9$ & 0,19 \\
\hline II & $90,3 \pm 17,0$ & & $99,1 \pm 23,9$ & \\
\hline III & $80,3 \pm 19,5$ & & $88,7 \pm 23,1$ & \\
\hline \multicolumn{5}{|l|}{ Terapi obat ${ }^{\#}$} \\
\hline Ya & $86,2 \pm 18,2$ & 0,73 & $94,2 \pm 23,7$ & 0,86 \\
\hline Tidak & $87,6 \pm 18,2$ & & $95,1 \pm 23,0$ & \\
\hline \multicolumn{5}{|l|}{ Citarasa } \\
\hline Memuaskan & $89,7 \pm 16,3$ & 0,15 & $95,1 \pm 20,1$ & 0,86 \\
\hline Tidak memuaskan & $84,0 \pm 19,6$ & & $94,2 \pm 25,6$ & \\
\hline \multicolumn{5}{|l|}{ Pendidikan pasien } \\
\hline Tinggi & $89,5 \pm 19,4$ & 0,34 & $97,3 \pm 27,9$ & 0,44 \\
\hline Rendah & $85,4 \pm 17,3$ & & $93,1 \pm 20,1$ & \\
\hline
\end{tabular}

${ }^{\$} y a=$ mengalami mual, muntah, atau diare, tidak = tidak mengalami mual, muntah, atau diare

${ }^{*} \mathrm{I}=$ faktor stres ringan, $\mathrm{II}=$ faktor stres sedang, III = faktor stres berat

\#ya = menyebabkan anoreksia, tidak = tidak menyebabkan anoreksia

baik dibandingkan dengan yang kurang dari 7 tahun Hal ini dikaitkan dengan tanggung jawab, pengalaman, dan keterampilan dalam melaksanakan tugas yang semakin meningkat (24). Hal tersebut bermanfaat untuk memenuhi tuntutan terhadap kasus yang ditangani dan memberikan kualitas hidup pasien yang lebih baik (25). Kepercayaan diri ahli gizi semakin meningkat setelah mendapatkan pemahaman tentang suatu kondisi dan kasus pasien secara spesifik, serta semakin memahami pola klinis yang dialami pasien. Peran aktif ahli gizi dari waktu ke waktu dalam menangani masalah pasien akan menumbuhkan kepercayaan dirinya (26).

\section{Asupan energi dan protein pasien menurut kinerja ahli gizi}

Penelitian ini menunjukkan tidak ada perbedaan persentase asupan gizi pasien berdasarkan kinerja ahli gizi. Hal ini mungkin disebabkan oleh kemampuan ahli gizi dalam mengedukasi pasien untuk menghabiskan makanan dari rumah sakit. Selain itu, kemungkinan juga karena pasien berusaha untuk menghabiskan makanan yang disediakan dari rumah sakit karena alasan supaya cepat sembuh dan pulang ke rumah.

Sebuah penelitian menunjukkan bahwa ahli gizi yang masa kerjanya lebih dari 7 tahun memiliki kinerja yang lebih baik dibandingkan dengan yang kurang dari 7 tahun. Hal ini dikaitkan dengan tanggung jawab, pengalaman, dan keterampilan dalam melaksanakan tugasnya pun semakin meningkat (24). Tetapi ada pernyataan bahwa pengalaman kerja yang sudah lama belum dapat menjamin seseorang itu lebih produktif daripada rekan kerjanya yang belum lama bekerja. Kinerja seseorang akan meningkat apabila ada kesesuaian antara kemampuan dan jenis pekerjaan yang dimilikinya (27). Ada beberapa kemampuan ahli gizi yang kurang diperhatikan sehingga menyebabkan permasalahan gizi yaitu tidak mendokumentasikan berat badan, tinggi badan, dan riwayat asupan makan, tidak memonitor nilai laboratorium pasien, serta penambahan kebutuhan gizi berkaitan dengan keadaan sakit, trauma, dan stress (28). Selain itu, 
kemampuan berkomunikasi seorang ahli gizi dalam berinteraksi dengan pasien, misalnya memberikan motivasi, edukasi, empati, dan sebagainya, dikembangkan dari pengetahuan dan keterampilan yang dimiliki. Pengetahuan dan keterampilan tersebut ditunjang dari tingkat pendidikan dan pelatihan yang pernah diikutinya (13).

\section{Kinerja menurut tingkat kepercayaan diri ahli gizi}

Berdasarkan hasil uji statistik dapat diketahui bahwa tidak ada perbedaan kinerja ahli gizi menurut tingkat kepercayaan diri ahli gizi. Hal ini mungkin disebabkan instalasi gizi memiliki standar operasional prosedur (SOP) yang harus dilaksanakan oleh ahli gizi rawat inap, sehingga setiap kewajiban yang diberikan, berusaha dikerjakan sebaik mungkin oleh masing-masing ahli gizi.

Dari berbagai permasalahan gizi yang ada setiap harinya di rumah sakit, ahli gizi dihadapkan pada berbagai pilihan untuk mengambil keputusan yang tepat dalam menangani pasien sebaik mungkin. Kepercayaan diri yang dimiliki ahli gizi akan membawanya merasa mampu dalam menangani kasus pasien. Rasa percaya diri mendasari kompetensi tenaga kesehatan untuk melakukan perawatan secara efektif (29). Faktor yang mempengaruhi kepercayaan diri seseorang salah satunya adalah pengetahuan. Pengetahuan ahli gizi yang terus ditingkatkan sangat penting untuk memberikan saran diet yang relevan sesuai dengan kebutuhan gizi pasien sehingga asupan gizi pasien menjadi baik (30). Kinerja yang diberikan kepada pasien pun menjadi maksimal. Ketaatan pasien terhadap diet yang diberikan merupakan tantangan bagi ahli gizi. Untuk mengatasi hal tersebut, setiap ahli gizi dianjurkan untuk merencanakan diet pasien, memberikan pengetahuan tentang komplikasi, misalnya terhadap gaya hidup, serta menetapkan tujuan yang akan diperoleh pasien. Untuk itu, ahli gizi memerlukan kepercayaan diri dalam perencanaan dan penyampaiannya (31).

Setiap jenis pekerjaan memiliki tuntutan yang berbeda-beda, misalnya sebagai ahli gizi rawat inap harus menjalankan salah satu tugasnya, yaitu melakukan PAGT terhadap pasien yang berisiko. Kemampuan masing-masing ahli gizi dalam menangani kasus pasien juga berbedabeda. Kinerja seseorang dengan sendirinya akan meningkat apabila ada kesesuaian antara kemampuan dan jenis pekerjaannya (27). Baik dan buruknya kinerja seseorang dipengaruhi oleh faktor internal dan eksternal. Faktor internal, yaitu kemampuan, usaha, umur, jenis kelamin, tingkat pendidikan, pengalaman, tujuan, persepsi, motivasi, nilai-nilai yang dianut, dan intelegensi, sedangkan faktor eksternal, yaitu tingkat pekerjaan, rekan kerja, gaya pemimpin, teknologi, dan komunikasi interpersonal $(32,33)$.

\section{Asupan gizi pasien menurut kondisi anoreksia, gangguan gastrointestinal, penyakit, terapi obat, cita rasa, dan pendidikan pasien}

Rerata persentase asupan gizi pada pasien yang mengalami anoreksia dan gastrointestinal lebih rendah secara bermakna dibandingkan dengan yang tidak. Penelitian ini tidak menunjukkan perbedaan rerata persentase asupan gizi berdasarkan penyakit, terapi obat, cita rasa makanan, dan pendidikan pasien.

Ketidakcukupan asupan gizi pasien salah satunya disebabkan oleh gangguan gastrointestinal yang sudah dirasakan pasien sejak awal hingga keluar rumah sakit. Ada pengaruh yang bermakna antara asupan makan terhadap ada tidaknya gejala gastrointestinal dan anoreksia yang dialami pasien (34).

Sebagian besar penyakit kronis atau penyakit berat yang mengakibatkan anoreksia dan berdampak pada malnutrisi. Pengembangan masalah malnutrisi sangatlah multifaktorial, namun penurunan asupan gizi, serta peningkatan kebutuhan energi dan protein kemungkinan memegang peranan penting (22). Asupan makan yang kurang salah satunya disebabkan oleh nafsu makan yang berkurang (35).

Proses penyembuhan penyakit, tidak hanya mengutamakan pemberian asupan makanan sesuai dengan kebutuhan pasien saja, melainkan juga perawatan, serta pengobatan terhadap penyakit. Tiga hal tersebut merupakan suatu kesatuan yang saling berkaitan (36). Kebanyakan penyakit infeksi 
berhubungan dengan asupan makan yang kurang, dapat dilihat pada beberapa penyakit, seperti gastroenteritis dan nyeri perut (35).

Tidak ada perbedaan rerata persentase asupan gizi terhadap penyakit mungkin terjadi karena setelah pasien diedukasi oleh ahli gizi, pasien menyadari bahwa diet yang diberikan dari rumah sakit merupakan bagian dari terapi penyembuhan penyakitnya, sehingga pasien termotivasi untuk menghabiskan makanannya. Sebuah penelitian menunjukkan bahwa tidak ada pengaruh pelaksanaan asuhan gizi terapi gizi medis dengan asupan gizi pasien penyakit jantung dan pembuluh darah $(12,37)$.

Tidak ada perbedaan rerata persentase asupan gizi yang bermakna secara statistik kemungkinan disebabkan oleh respon yang dialami seseorang terhadap suatu obat berbeda satu dengan yang lainnya. Pasien memiliki keragaman respon obat atau metode pengobatan yang sama (38). Selain itu, kondisi patologis dan fisiologis pasien juga mempengaruhinya dalam merespon terapi obat tertentu (39).

Tidak ada perbedaan rerata persentase asupan gizi terhadap citarasa makanan yang bermakna dalam penelitian ini. Pasien menerima makanan yang disediakan oleh rumah sakit, karena dari hasil yang didapat, pasien yang tidak puas terhadap cita rasa makanan rerata persentase asupannya tidak rendah. Namun demikian, terkadang pasien merasa bosan dengan makanan rumah sakit. Ada beberapa yang sengaja mengonsumsi makanan dari luar.

Tidak ada perbedaan rerata persentase asupan gizi menurut tingkat pendidikan, kemungkinan karena setiap pasien mendapatkan makanan yang sama dari rumah sakit dan mendengarkan hal yang telah diedukasikan oleh ahli gizi tentang jenis diet yang didapat, makanan yang dianjurkan dan tidak, termotivasi untuk selalu menghabiskan makanan dari rumah sakit, serta meminimalisasi makanan dari luar rumah sakit.

Ahli gizi ditantang untuk berpikir kreatif dalam menangani pasien yang mengalami anoreksia atau gangguan gastrointestinal, tetapi asupan gizinya tetap terpenuhi. Perlu adanya kerjasama antara ahli gizi dengan tenaga medis lainnya dalam menangani kondisi pasien. Keterbatasan penelitian ini, yaitu hanya menggunakan kuesioner tingkat kepercayaan diri yang tidak dapat melihat perubahan kepercayaan diri ahli gizi. Penelitian ini memiliki outlier, sehingga mempengaruhi power penelitian. Kuesioner kinerja ahli gizi tidak memasukkan tahap monitoring dan evaluazi gizi pasien. Asupan pasien hanya dibatasi asupan oral saja.

\section{KESIMPULAN DAN SARAN}

Tidak ada perbedaan antara asupan gizi pasien menurut tingkat kepercayaan diri dan kinerja ahli gizi dalam menerapkan PAGT.Tidak terdapat pula perbedaan kinerja ahli gizi menurut tingkat kepercayaan diri ahli gizi. Bagi peneliti lain perlu mengembangkan kuesioner kinerja ahli gizi dengan memasukkan tahapan monitoring dan evaluasi gizi pasien, misalny tren kenaikan asupan pasien dari hari ke hari, kesesuaian diet, dan sebagainya, serta mengikutsertakan pasien yang menerima dukungan gizi, baik enteral maupun parenteral. Setiap komponen di kuesioner kinerja perlu diuji validitas dan reliabilitasnya, serta perlu dilakukan penilaian secara kualitatif untuk mengetahui kinerja masing-masing ahli gizi.

\section{RUJUKAN}

1. Correia MICA. Prevalence of hospital malnutrition in Latin America: the multicenter ELAN study. Nutrition. 2003;19(10):823-5.

2. Correia $M, W a i t z b e r g ~ D$. The impact of malnutrition on morbidity, mortality, length of hospital stay and costs evaluated through a multivariate model analysis. Clin Nutr. 2003;22(3):235-9.

3. Kahokehr A, Sammour T, Wang K, Sahakian V, Plank L, Hill A. Prevalence of malnutrition on admission to hospital - acute and elective general surgical patients. Eur Clin Nutr Metab. 2010;(5):21-5.

4. Chakravarty C, Hazarika B, Goswami L, Ramasubban S. Prevalence of malnutrition in a tertiary care hospital in India. Indian journal of critical care medicine : peer-reviewed. Indian J Crit Care Med. 2013;17(3):170-3. 
5. Budiningsari R, Hadi $H$. Pengaruh perubahan status gizi pasien dewasa terhadap lama rawat inap dan biaya rumah sakit. J Gizi Klin Ind. 2004;1:30-40.

6. Julianty A. Malnutrisi rumah sakit pada bangsal anak Rumah Sakit Dr. Wahidin Sudirohusodo Makassar. Sari Pediatr. 2013;15(2):65-8.

7. Sidiartha I. Insiden malnutrisi rawat inap pada anak balita di Rumah Sakit Umum Pusat Sanglah Denpasar. Sari Pediatr. 2008;9(6):381-5.

8. DeBruyne L, Pinna K, Whitney E. Nutrition and diet therapy: principles and practice, 7 th ed. USA: Thompson; 2008.

9. Bavelaar J, Otter C, van Bodegraven A, Thijs A, van Bokhorst-de van der Schueren M. Diagnosis and treatment of (disease-related) in-hospital malnutrition: the performance of medical and nursing staff. Clin Nutr. 2008;27(3):431-8.

10. Kondrup J, Johansen N, Plum L, Bak L, Larsen I, Martinsen A. Incidence of nutritional risk and causes of inadequate nutritional care in hospitals. Clin Nutr. 2002;21(6):461-8.

11. Naber T, Schermer T, de Bree A, Nusteling $K$, Eggink L, Kruimel J. Prevalence of malnutrition in nonsurgical hospitalized patients and its association with disease complications. Am J Clin Nutr. 1997;66(5):1232-9.

12. Chasbullah I. Pengaruh pelaksanaan asuhan gizi dengan pendekatan terapi gizi medis terhadap asupan makanan dan lama rawat di Rumah Sakit Umum Kota Bekasi. J Gizi Klin Ind. 2008;5:1-8.

13. Sumapradja M, Fayakun $Y$, Widyastuti D. Proses asuhan gizi terstandar (PAGT). Jakarta: Abadi Publishing \& Printing; 2011.

14. Lacey K, Pritchett E. Nutrition care process and model: ADA adopts road map to quality care and outcomes management. J Am Diet Assoc. 2003;103(8):1061-72.

15. Mcneil S, Shearer J, Johnson R, Kent S, Klein $\mathrm{C}$, McClusky K. American dietetic association revised 2008 standards of practice for registered dietitians in nutrition care; standards of professional performance for registered dietitians; standards of practice for dietetic technicians, registered, in nutrition care; a. J Am Diet Assoc. 2008;108(9):1538-42.
16. Sandrick K. Is nutritional diagnosing a critical step in the nutrition care process? J Am Diet Assoc. 2002;102(3):427-31.

17. Adib Hagbaghery M, Salsali M, Ahmadi F. A qualitative study of Iranian nurses' understanding and experiences of professional power. Hum Resour Health [Internet]. 2004 Dec 24;2(1):9. Available from: http://human-resources-health. biomedcentral.com/articles/10.1186/1478-44912-9

18. Davis D, Campbell C, Poste J, Ma G. The association between operator confidence and accuracy of ultrasonography performed by novice emergency physicians. J Emerg Med. 2005;29(3):259-64.

19. Sergeev I, Lipsky A, Ganor O, Lending G, Abebe-Campino G, Morose A. Training modalities and self-confidence building in performance of life-saving procedures. Mil Med. 2012;177(8):901-6.

20. Lemeshow S, DWH J, Klar J, Lwanga S. Besar sampel dalam penelitian kesehatan. Yogyakarta: Gadjah Mada University Press; 1997.

21. Lauster P. Tes kepribadian. Jakarta: Bumi Aksara; 2008.

22. Norman K, Pichard C, Lochs H, Pirlich M. Prognostic impact of disease-related malnutrition. Clin Nutr. 2008;27(1):5-15.

23. Mowe M, Bosaeus I, Rasmussen $\mathrm{H}$, Kondrup $\mathrm{J}$, Unosson $\mathrm{M}$, Irtun $\mathrm{O}$. Nutritional routines and attitudes among doctors and nurses in Scandinavia: a questionnaire based survey. Clin Nutr. 2006;25(3):524-32.

24. Utami N. Analisis beban kerja dan kinerja dietisien dalam melaksanakan nutrition care process di Tuang Rawat Inap Rumah Sakit Hasan Sadikin Bandung. Universitas Gadjah Mada; 2011.

25. Lu A, Dollahite J. Assessment of dietitians' nutrition counselling self-efficacy and its positive relationship with reported skill usage. J Hum Nutr Diet. 2010;23(2):144-53.

26. Hoifodt T, Talseth A, Olstad R. A qualitative study of the learning processes in young physicians treating suicidal patients: from insecurity to personal pattern knowledge and self-confidence. BMC Med Educ. 2007;7:21. 
27. Muchlas M. Perilaku organisasi. Yogyakarta: Gadjah Mada University Press; 2005.

28. Syamsiatun N, Hadi H, Julia M. Hubungan antara status gizi awal dengan status pulang dan lama rawat inap pasien dewasa di rumah sakit. J Gizi Klin Ind. 2004;1(1):23-9.

29. Porter J, Morphet J, Missen K, Raymond A. Preparation for high-acuity clinical placement: confidence levels of final-year nursing students. Adv Med Educ Pr. 2013;4:83-9.

30. Moore H, Greenwood D, Gill T, Waine C, Soutter $\mathrm{J}$, Adamson A. A cluster randomised trial to evaluate a nutrition training programme. $\mathrm{Br} \mathrm{J}$ Gen Pr. 2003;53(489):271-71.

31. Williamson A, Hunt A, Pope J, Tolman N. Recommendations of dietitians for overcoming barriers to dietary adherence in individuals with diabetes. Diabetes Educ. 2000;26(2):272-9.

32. Bailey R. Human performance engineering: a guide for system designers. New Jersey: Prentice-Hall; 1990.

33. Bateman T, Ferris G, Strasser S. Kinerja. Jakarta: Elex Media Komputindo; 1992.
34. Dwiyanti D, Hadi $H$, Susetyowati. Pengaruh asupan makanan terhadap kejadian malnutrisi di rumah sakit. J Gizi Klin Indones. 2004;1(1):1-7.

35. Tomkins A, Watson F. Malnutrition and infection a review. Switzerland: ACC/SCN; 1989.

36. Kusumayanti I, Hadi H, Susetyowati. Faktorfaktor yang mempengaruhi kejadian malnutrisi pasien dewasa di ruang rawat inap rumah sakit. J Gizi Klin Ind. 2004;1(1):8-15.

37. Pakaya A. Pengaruh pelaksanaan asuhan gizi dengan pendekatan terapi gizi medis (TGM) terhadap intake makanan dan status gizi pasien rawat inap RSUD Dr. M.M Dunda dan RSUD Prof Dr. Aloe Saboe Gorontalo. Universitas Gadjah Mada; 2009.

38. Ross E, Kenakin T. Farmakodinamika: mekanisme kerja obat dan hubungan antara konsentrasi obat dan Eefek. Jakarta: EGC; 2003.

39. Holford N. Pharmacokinetics and pharmacodynamics: rational dosing and the time course of drug action. Singapore: McGraw Hill; 2009. 